\title{
ANALISIS DESAIN KEMASAN MI U.F.O NISSIN FOOD
}

\author{
Rizky Ramadhina ${ }^{1)}$, Dara Masrina Ilyas ${ }^{2)}$ \\ Program Studi Desain Komunikasi Visual \\ Fakultas Bahasa dan Seni, Universitas Indraprasta PGRI \\ JL. Nangka No 58 C, Tanjung Barat,Jakarta 12530, Indonesia. \\ Rizkiramadhina@gmail.com
}

\begin{abstract}
Abstrak
Kemasan merupakan sebuah pemicu agar terjadi transaksi pembelian karena kemasan akan berhadapan langsung dengan konsumen, kemasan harus mampu memberikan impresi atau kesan positif terhadap konsumen. Tujuan dari penelitian ini adalah untuk menganalisis desain dalam kemasan suatu produk dari Nissin Food yaitu Mi U.F.O dari segi warna, bentuk, dan logo dalam pengaruhnya untuk meningkatkan penjualan produk yang dikemasnya dengan menggunakan teori daya tarik visual dan daya tarik praktis, penelitian akan dilakukan dengan menggunakan metode penelitian kualitatif dengan studi literatur dari berbagai sumber yaitu Buku, Jurnal dan artikel Online. Hasil dari penelitian ini adalah bentuk analisis dari kemasan produk Mi U.F.O yang diharapkan bisa berguna untuk mahasiswa memahami kajian desain kemasan dan bagi pengusaha bisnins makanan produk serupa.
\end{abstract}

Kata Kunci: Desain kemasan, Mi Instan, Nissin Food, Mi U.F.O

\begin{abstract}
Packaging is a trigger for a purchase transaction to occur because its function is directly dealing with consumers, packaging must be able to give impressions or positive impressions to consumers. The purpose of this study was to analyze the design in packaging a product of Nissin Food's Mi U.F.O in terms of color, shape, and logo in its influence to increase the sales of the products it packs using the theory of visual attraction and practical attractiveness, research will be conducted using qualitative research methods with literature studies from various sources namely Books, Journals and Online articles. The results of this study are a form of analysis of the packaging of Mi U.F.O products which are expected to be useful for students to understand the study of packaging design and for entrepreneurs in the food business of similar products.
\end{abstract}

Keywords: Packaging Design, Instant Noodles, Nissin Food, Mi U.F.O

Correspondence author: Rizky Ramadhina, Rizkiramadhina@gmail.com, Jakarta, Indonesia 


\section{PENDAHULUAN}

Mi instan muncul di Indonesia pada tahun 1969, banyak yang meragukan kehadiran mi instan yang diperkenalkan sebagai salah satu bahan pangan pokok akan tetapi, karena harganya yang terjangkau, mudah disajikan dan awet mi instan lama kelamaa diterima oleh masyarakat Indonesia. Terdapat benyak merek mi instan yang diproduksi oleh perusahaan-perusahaan makanan di Indonesia, antara lain Indomie, Mie Sedap, dan Nissin. Nissin merupakan perusahaan yang pertama didirikan Momofuku Ando asal Jepang

Mi instan pertama kali diciptakan oleh Momofuku Ando pada 1958, kemudian Momofuku mendirikan perusahaan Nissin yang mulai memproduksi produk mi instan pertama yang ada di dunia yaitu Chicken Ramen rasa ayam. Peristiwa lainnya terjadi pada 1972 saat Nissin memperkenalkan mi dalam kemasan gelas dengan merek Cup Noodle. Kemasannya adalah wadah Styrofoam yang tahan air dan bisa sekaligus digunakan untuk memasak mi tersebut. Inovasi yang lainnya adalah menambahkan sayuran kering ke gelas sebagai bahan pelengkap hidangan mi tersebut. Pada Juni 1980, kesukesan mi instan dan mi instan cup menyebar ke seluruh dunia dan perusahaan Ando mulai melebarkan bisnisnya ke seluruh dunia mulai dari Brazil,Amerika, Singapore dan akhirnya Indonesia, tidak hanya mengekspor mi instannya, tetapi juga mengembangkan produk yang sesuai dengan cita rasa dari negeri asal. Pada Juni 2016 Nissin Food meluncurkan produk mie U.F.O rasa saus jepang yang merupakan mi instan dengan kemasan plastik berbentuk mangkuk.

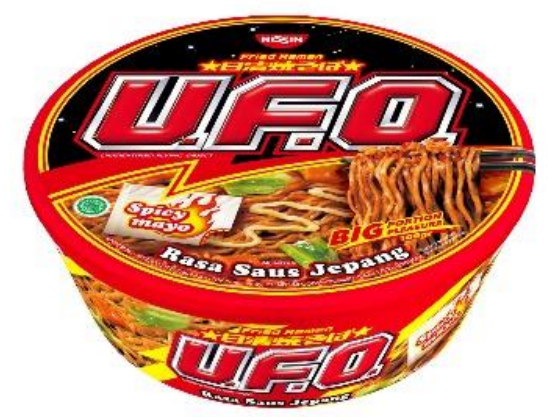

Gambar 1 Nissin Food U.F.O Rasa saus Jepang

Tujuan dari penelitian ini adalah untuk menganalisis desain kemasan dari produk Nissin Food Mi U.F.O dengan pendekatan teori daya tarik visual dan daya tarik praktis, manfaat dari penelitian ini diharapkan agar mahasiswa lebih memahami konsep desain kemasan suatu produk dan agar semakin banyak pengusaha berinovasi membuat kemasan produk yang lebih menarik.

\section{Tinjauan Pustaka}

\section{Teori Kemasan}

Kemasan adalah suatu desain kreatif yang bersangkutan dengan bentuk, struktur, material, warna, citra, tipografi, dan elemen elemen desain dengan infrormasi produk agar produk bisa ditawarkan dan dipasarkan kepada konsumen. Kemasan dapat digunakan untuk membungkus, melindungi, mengirim, mengeluarkan, menyimpan, juga untuk mengidentifikasi dan membedakan sebuah produk yang ada dipasaran (Klimchuck \& Krasovec, 2007: 33).

\section{Fungsi kemasan}

Kemasan menurut Sri Julianti (Julianti, 2014) adalah wadah yang dapat meningkatkan fungsi dan nilai dari sebuah produk. Dari definisi tersebut maka terdapat beberapa fungsi kemasan, yaitu:

1. Melindungi kualitas produk

2. Membuat produk lebih tahan lama

3. Sebagai sarana komunikasi produk dan branding kepada konsumen 
4. Membantu distribusi produk dari produsen sampai ke tangan konsumen.

5. Membuat produk dapat diproduksi secara massal

6. Menjadi pemicu minat beli dengan merangsang lima panca indera konsumen yang melihat, mendengar, membaui, merasa, sampai ada keputusan membeli dan menggunakan produk.

Sri Julianti juga mengatakan bahwa kemasan harus mempunyai fungsi strategis yang harus mampu memberikan positioning baru dan daya ungkit bagi suatu produk. Berdasarkan fungsinya, kemasan bisa dibagi menjadi dua, yaitu:

1. Kemasan primer

Yaitu keseluruhan kemasan yang dipajang dan berfungsi untuk membuat konsumen memutuskan membeli produk tersebut atau tidak. Kemasan primer ini sangat penting untuk melindungi, komunikasi ke pelanggan dan memiliki fungsi artistik agar konsumen yang melihat bisa tertarik untuk membeli produk tersebut.

2. Kemasan sekunder

Biasa disebut sebagai transport packaging yang dibutuhkan untuk menjaga kemasan primer saat menyimpannya di gudang serta saat didistribusikan ke pelanggan dalam partai besar maupun ecerean. Kemasan sekunder merupakan satu kemasan dengan kemasan primer dan biasanya menggunakan bahan lebih fleksibel, kemasan sekunder perlu lebih kuat daripada kemasan priemrnya agar produk maupun kemasan primer tetap terlindung.

Berdasarkan material atau bahan bakunya, kemasan dapat dibagi menjadi beberapa macam, seperti:

1. Natural atau dari alam: daun, bamboo dan kayu

2. Kertas dan karton, termasuk karton gelombang

3. Plastic dan rigid dan semi-rigid

4. Fleksibel

5. Gelas

6. Logam: alumunium dan baja

\section{Prinsip Desain Kemasan}

Ada banyak variabel yang memengaruhi mengapa desain kemasan menjadi faktor untuk menarik konsumen. Empat penarik perhatian utama di dalam suatu kemasan adalah sebagai berikut:

1. Warna

2. Struktur fisik atau bentuk

3. Simbol dan angka

4. Tipografi

\section{Daya Tarik Kemasan}

Daya tarik kemasan dapat dibagi menjadi dua, yaitu:

1. Daya Tarik Visual (Estetika)

Daya tarik visual yang mengacu pada penampilan kemasan dan mencakup semua unsur grafis seperti warna, bentuk, merek atau logo, ilustrasi, tipografi, dan tata letak ini dikombinasikan untuk menciptakan kesan yang menimbulkan daya tarik visual secara optimal kepada konsumen. Daya tarik visual sendiri berkaitan dengan faktor emosi dan psikologis seseorang.

2. Daya Tarik Praktis (fungsional)

Daya tarik praktis adalah suatu efisiensi dari kemasan yang diperuntukkan kepada konsumen dan juga distributor, misalnya untuk memudahkan penyimpanan dan pemajangan produk. Faktor-faktor daya tarik praktis (fungsional), adalah sebagai berikut:

a. Faktor pengamanan

Kemasan melindungi produk dari berbagai kemungkinan timbulnya kerusakan misalnya, cuaca panas, jatuh, bertumpukan, serangga dan lain-lain. Contohya, kemasan wafer yang bisa ditutup kembali untuk mempertahankan kerenyahannya. 
b. Faktor ekonomi

Perhitungan biaya produksi yang efektif agar biaya tidak melebihi proporsi manfaat dari produk. Contohnya, produk-produk isi ulang, produk-produk susu atau makanan bayi dalam kardus.

c. Faktor pendistribusian

Kemasan harus mudah di distribuskan dari pabrik ke distributor sampai ke tangan konsumen. Di distributor, kemudahan untuk penyimpanan dan pemajangan harus dipertimbangkan. Bentuk dan ukuran kemasan direncanakan dan dirancang agar peletakkan dan pemajangan tidak sulit

d. Faktor komunikasi

Maksudnya adalah kemasan mempunyai tugas untuk menjelaskan produk, citra merek. Faktor komunikasi dalam kemasan adalah agar kemasan mudah dilihat, dipahami dan diingat.

e. Faktor Ergonomik

Pertimbangan agar kemasan mudah dibawa kemanapun dan mudah untuk dipegang, dibuka dan diambil sangatlah penting karena akan mempengaruhi bentuk dari kemasan tersebut dan juga mempengaruhi kenyamanan konsumen. Contohnya, produk susu Greenfield yang mempunyai bentuk kotak tapi disisinya dibuat agak melengkung unutk memudahkan konsumen memegang produk susu tersebut.

f. Faktor identitas

Kemasan harus berbeda secara keseluruhan dengan kemasan merek lain, ini berfungsi agar produk yang dipasarkan memilki ciri khas tersendiri agar mudah dibedakan dan dikenali konsumen yang melihat.

g. Faktor promosi

Kemasan sangat penting dalam bidang promosi, kemasan bisa disebut sebagai silent sales person. Kemasan efektif untuk menarik perhatian konsumen baru ataupun konsumen yang sudah lama.

h. Faktor lingkungan

Masyarakat sekarang mengkhawatirkan masalah mengenai polusi dan pembuangan sampah, salah satulimbah kemasan yang menjadi topic hangat tahun 1990-an adalah stereofoam tetapi banyak organisasi-organisasi lingkungan hidup berhasil menekan beberapa perusahaan untuk membuat kemasan tersebut ramah lingkungan dan bisa didaur ulang.

\section{Warna}

Warna adalah aspek yang punya pengaruh besar dalam desain kemasan. Konsumen mengidentifikasi warna kemasan suatu produk sebelum unsur visual lainnya di dalam kemasan. Warna dalam kemasan berfungsi untuk membedakan kepribadian merek, dam menarik perhatian ke atribut-atribut lainnya, agar produk mempunyai perbedaan dengan pesaing (Erlyana \& Nadya, 2018)

Warna bisa digunakan untuk identitas brand, yaitu ketika sebuah brand menggunakan satu warna tertentu dalam kurun waktu yang lama dan konsisten menggunakannya maka konsumen akan mengidentikan satu warna tersebut terhadap suatu brand, contohnya seperti produk Pepsi yang identik dengan warna birunya dan Coca-cola identik dengan warna merahnya, kedua warna dapat menjadi pembeda antara satu varian produk dalam satu brand, ketiga warna juga digunakan untuk membedakan suatu produk dengan produk lain yang sama dipasaran, dengan begini konsumen akan lebih mudah dalam menyeleksi dan menemukan produk yang ingin mereka beli sesuai dengan kebutuhan mereka.

Jill Morton, seorang konsultan warna dan CEO perusahaan ColorCom menyatakan, bahwa sebagai alat marketing, warna bisa menjadi kekuatan persuasive bawah sadar konsumen. Juga sebagai suatu komponen fungsional dari pengelihatan manusia, warna bisa menjadi penarik perhatian, bisa menyejukkan atau menyakitkan mata yang melihat dan memiliki berkontribusi 
pada kesuksesan suatu produk, jasa atau bahkan suatu interior ruangan. Warna yang salah dapat menjadi kesalahan yang mahal.”(Klimchuck \& Krasovec, 2007:107)

\section{Terminologi warna}

Warna mengkomunikasikan secara psikologis dengan menciptakan suatu asosiasi mental. Asosiasi mental terhadap warna inilah yang menentukan persepsi seseorang tentang suatu obyek atau lingkungan sekitarnya. Meskipun orang dalam lingkungan yang sama mempunyai asosiasi mengenai warna secara umum yang hampir sama, reaksi individu terhadap warna dipengaruhi juga oleh latar belakang budaya dan interpretasi sosial secara umum. Walaupun konotasi warna berubah seiring perubahan wakru, bagi pengguna dari latar belakang budaya dan geografi yang mirip makna fudamental dari warna tetaplah konsisten (Klimchuck \& Krasovec, 2007: 107).

\section{Asosiai Warna bervariasi}

Warna mempunyai makna dan asosiasi terhadap sesuatu dalam kehidupan manusia, berikut adalah asosiasi warna dan maknanya:

1. Merah, diasosiasikan dengan matahari, panas,sifat impulsif, warna merah yang intens mengkomunikasikan kecanggihan, efektivitas, keotentikan. Dalam desain kemasan warna merah umumnya digunakan untuk menarik perhatian karena dapat menggambarkan intensitas suatu rasa pedas, panggang atau panas dan bisa menggambarkan rasa buah (apel, strawberry, ceri).

2. Oranye, sering dikaitkan dengan kehangatan sinar matahari. Warna oranye bisa mengomunikasikan citra merek yang kuat juga energik, dalam produk perawatan tubuh biasanya oranye berkaitan dengan perawatan kulit dan pelindung matahari.

3. Kuning, melambangkan kehidupan, idealisme, energi. Dalam batas yang wajar warna kuning dapat menjadi warna paling menarik perhatian, warna kuning bisa digunakan untuk menggambarkan rasa buah jeruk atau mentega, dalam produk rumah tangga bisa mengkomunikasikan keefektifan dan kehati-hatian.

4. Hijau, melambangkan wara yang membumi, damai, muda, segar. Warna hijau dapat mengkomunikasikan ramah lingkungan, daur ulang, kemakmuran, keberuntungan dan dianggap warna paling sejuk di mata. Dalam desain kemasan warna hijau dipakai untuk mengkomunikasikan rasa asam, apel dan jeruk nipis.

5. Biru, melambangkan kesetiaan, kebenaran, juga kebijaksanaan dan bisa melambangkan rasa depresi, dan kesepian. Dalam desain kemasan warna biru sering kali diasosiasikan dengan kekuatan, kepercayaan dan keyakinan.

6. Hitam, menggambarkan keras kepala, kebijaksanaan serta mengesankan kekuatan. Warna hitam dalam desain kemasan biasanya membantu untuk menonjolkan warna lain di sekitarnya.

\section{Ilustrasi}

Ilustrasi adalah suatu elemen desain yang membantu pembaca agar bisa menggambarkan apa yang tertulis dalam suatu tulisan, maupun cerita. Ilustrator yang baik harus berperan sebagai visualizer atau seseorang yang memvisualisasikan sebuah naskah. Ilustrasi mempunyai berbagai macam jenis antara lain karya seni yaitu lukis, sketsa, karikatural, grafis dan lain-lain. Seiring dengan perkembangan teknologi, terdapat ilustrasi dengan bentuk image, bitmap, vector, hingga karya foto (Everlin \& Yosephine, 2018).

Berikut adalah teknik-teknik dalam ilutrasi yang digunakan pada desain media:

1. Teknik Fotografi

Adalah berupa gambaran yang dihasilkan dengan teknik fotografi menggunakan kamera. Foto yang dihasilkan kamera digital dapat diolah lebih lanjut untuk memberikan ekspresi tetentu sesuai keinginan.

2. Teknik Line Art

Teknik ini adalah setiap gambar yang terdiri dari garis-garis lurus atau melengkung yang berbeda ditempatkan berlawanan dengan latar belakang yang polos tanpa adanya gradasi di 
tempat gelap berwarna untuk mewakili benda dua dimensi. Line art menekankan bentuk dan garis, warna, shading dan tekstur.

3. Teknik Flat Design

Adalah desain dengan pendekatan minimalis, biasanya desain bersih tanpa ada bayangan, tekstur, lalu berfokus pada tipografi, menggunakan warna-warna cerah dan ilustrasi yang bersifat dua dimensi. Gambar yang sederhana dapat meyampaikan pesan lebih cepat daripada ilustrasi yang terlalu detail. Contohnya gambar ikon yang dapat menunjukan suatu tindakan atau tujuan secara universal agar dapat mudah dimengerti oleh yang melihatnya.

4. Teknik Gabungan

Yaitu bentuk komunikasi dengan struktur visual yang terwujud dari perpaduan teknik fotografi atau ilustrasi manual dengan teknik menggambar di komputer

\section{Tipografi}

Adalah ilmu yang mempelajari tentang huruf, tipografi digunakan sebagai pedoman untuk mendasain tulisan-tulisan yang akan digunakan pada suatu produk baik pada iklan maupun kemasannya. Tipe huruf yang ada dalam ilmu tipografi adalah sebagai berikut:

1. Huruf Serif

Mempunyai ciri khasnya yaitu memiliki garis-garis kecil di setiap ujung hurufnya. Contoh dari tipe serif yaitu Book Antiqua, Garamond, Times New Roman dan Georgia.

2. Huruf Sans Serif

Tipe ini tidak memiliki garis-garis kecil di setiap ujung hurufnya, dan memiliki karakteristik streamline, modern, kontemporer dan fungsional. Contohnya Arial, Gothic dan Franklin Gothic.

3. Huruf Script

Tipe ini menyerupai tulisan tangan, contoh tulisan tipe huruf Script adalah Lucida Handwriting, Freeport, Monotype Corsiva.

Dalam mendesain kemasan, tipografi yang digunaan harus mudah dibaca dari jarak beberapa kaki jauhnya. Selain itu, tipografi kemasan juga diharapkan mampu untuk mengomunikasikan informasi produk dengan jelas (Klimchuck \& Krasovec, 2007: 92).

\section{METODE PENELITIAN}

Penelitian ini menggunakan metode kualitatif deskriptif bertujuan untuk menggambarkan, menjelaskan dan memvalidasi fenomena sosial yang menjadi subjek penelitian. Metode penelitian deskriptif adalah penelitian naratif yang digunakan dalam proyek penelitian kualitatif atau kualitatif.di mana penulis melakukan analisis berdasarkan teori-teori yang terkait dengan sumber buku, jurnal, dan artikel online. Fakta-fakta pada objek penelitian terkait subjek penelitian akan dideskripsikan yang mengacu pada konsep-konsep yang digunakan berdasarkan pemahaman peneliti sehingga akan muncul sebuah simpulan.

\section{HASIL DAN PEMBAHASAN}

Pembahasan analisis kemasan mie U.F.O Nissin Food dilakukan berdasarkan dengan teori daya tarik visual dan daya tarik praktis pada kemasan.

\section{Analisis Kemasan mie U.F.O Nissin Food}

\section{Daya Tarik Visual}

1. Warna

Warna yang digunakan pada kemasan primer yang terlihat dari luar ini adalah warna merah yang mencolok, menurut klimchuk dan krasovec warna merah mampu mempercepat dan meningkatkan tekanan darah dan dalam deain kemasan berfungsi sebagai pemikat perhatian, warna merah disini juga mengindikasikan rasa dari mie U.F.O sendiri yaitu rasa pedas, lalu terdapat sedikit warna hitam dibagian atas yang dimana fungsi warna hitam adalah sebagai warna pembantu yang membantu menonjolkan warna merah di sekitarnya, sedangkan warna 
untuk kemasan Primer didalamnya adalah warna putih dengan paduan hitam dan merah untuk petunjuk penyajian produk.

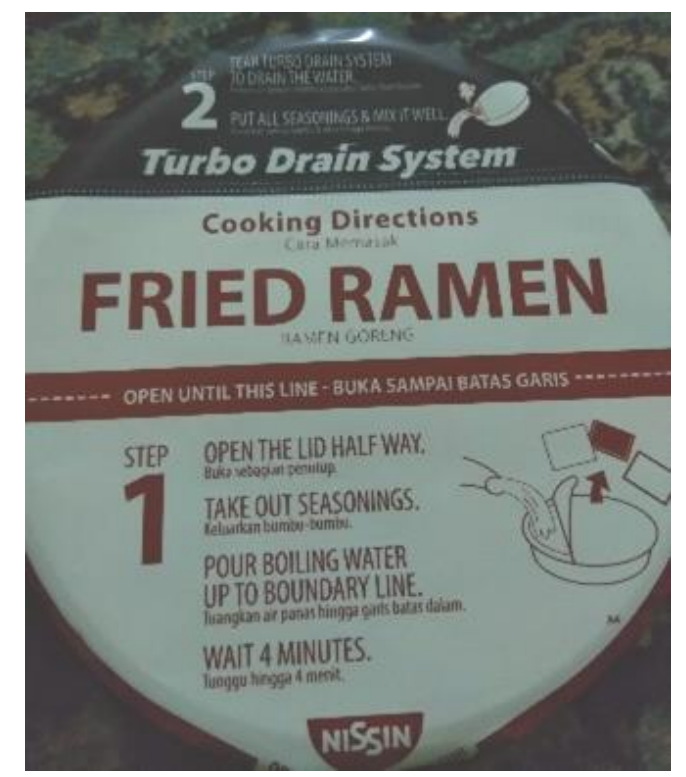

Gambar 3 Penggunaan Warna dalam Kemasan

2. Bentuk

Bentuk kemasan dari mie U.F.O ini adalah kemasan plastic polypropylene dan berbentuk seperti mangkuk bulat, desain seperti mangkuk ditujukan agar konsumen bisa memasak produk di wadah tersebut dan langsung memakannya seperti layaknya memakan mie olahan dalam mangkuk.

3. Merek/Logo

Merek/logo diletakan di bagian atas dengan ukuran kecil tetapi masih terlihat jelas walaupun logo berwarna merah tetapi menggunakan kontras merah yang berbeda dengan keseluruhan warna merah yang ada di kemasan.

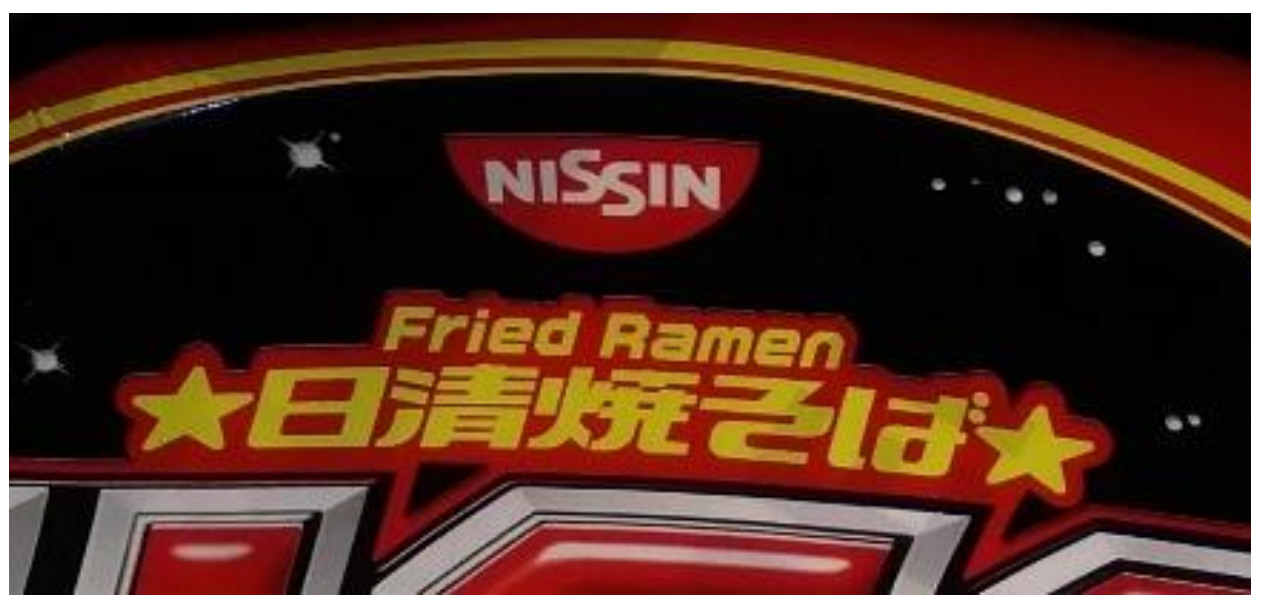

Gambar 4 Penggunaan merek/ Logo dalam kemasan

4. Ilustrasi

Ilustrasi pada kemasan mi U.F.O ini menggunakan ilustrasi foto. Foto yang ditampilkan adalah bentuk produk didalam kemasan apabila telah dimasak yang memberi gambaran pada 
konsumen bagaimana produk telah siap disantap.teknik foto yang digunakan adalah extreme close-up pada produk mi yang terlihat diangkat menggunakan sumpit.

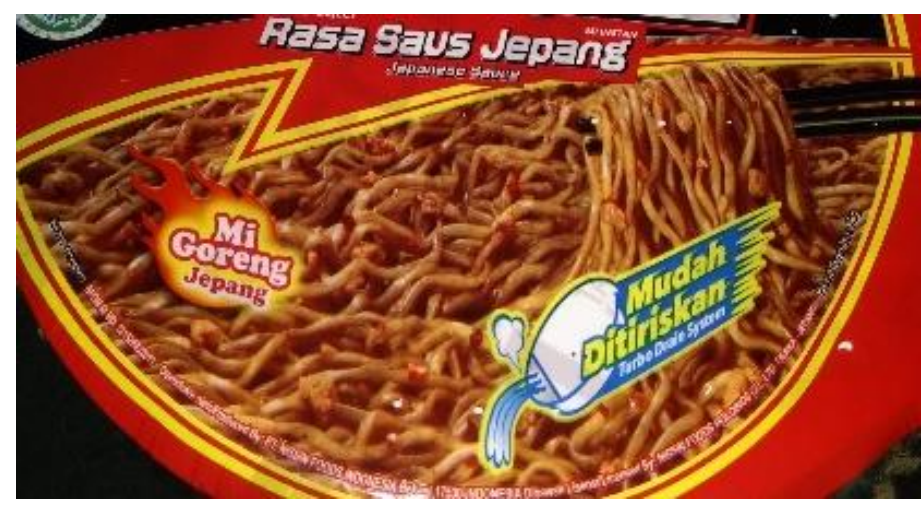

Gambar 5 Penggunaan Ilustrasi dalam Kemasan

5. Tipografi

Tipografi yang digunakan oleh mi U.F.O untuk tulisan U.F.O ini adalah sans serif yang memiliki tingkat keterbacaan yang baik dengan ukuran yang lumayan besar sehingga terlihat dari jarak jauh. Sedangkan untuk tulisan keterangan varian menggunakan tipografi jenis serif dengan tingkat keterbacaan baik dan ukuran yang sedang.

6. Tata Letak

Kemasan sudah disertai dengan informasi komposisi bahan-bahan pembuatan mi U.F.O dalam bahasa Indonesia dan Inggris, sudah disertai informasi gizi dan tanggal kadaluarsa, kemasan juga sudah memuat petunjuk bagaimana menyeduh mi U.F.O ini. Semua informasi tersebut ditempatkan di bagian bawah kemasan, sayangnya karna bentuk kemasan yang bulat, dan ukuran font yang tidak begitu besar bisa membuat konsumen yang membaca harus lebih teliti jika ingin membacanya.

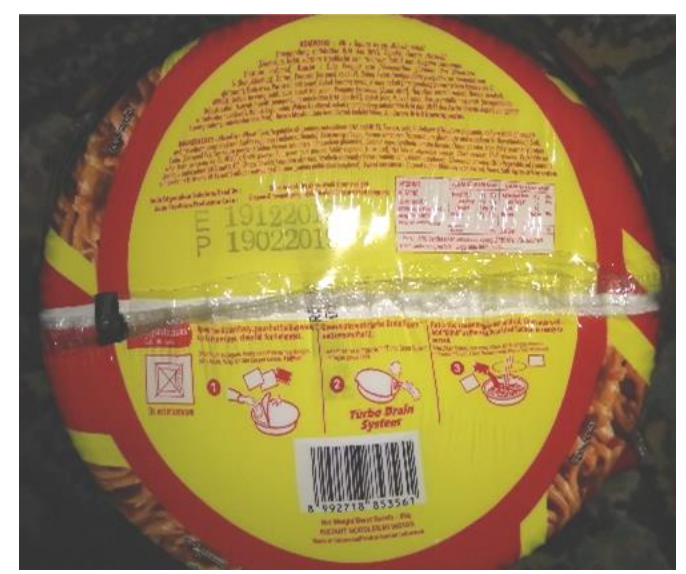

Gambar 6 Tata letak

Daya Tarik Praktis

1. Faktor pengamanan

Pengamanan kemasan cukup baik untuk melindungi isi produk, kemasan terbuat dari kemasan luar dari plastik yang tahan terhadap air dan udara, sedangkan kemasan dalam juga terbuat dari plastik yang tahan terhadap faktor cuaca dan udara juga sehingga sangat menjaga isi produk. 
2. Faktor ekonomi

Kemasan menggunakan dua macam tipe plastik yaitu tipe plastik sekali pakai dan plastik polypropylene, jenis plastik ini bagus untuk menjadi wadah makanan karena memiliki ketahanan terhadap lemak dan stabil terhadap suhu tinggi, jenis plastik ini juga bisa diolah kembali menjadi garpu, nampan dan lain-lain. Walaupun secara biaya akan lebih tinggi karena penggunaan 2 jenis plastik tetapi penggunaan plastik yang masih bisa diolah setidaknya membantu mengurangi sampah plastik sekali pakai.

3. Faktor Distribusi

Kemasan yang digunakan memudahkan pendistribusian karena kemasan yang kuat terhadap faktor cuaca, tetapi dalam peletakan di rak, produk cukup memakan tempat karena ukuran dan bentuknya yang lebar dan besar.

4. Faktor Komunikasi

Kemasan mi U.F.O ini sudah baik dalam segi komunikasinya karena sudah cukup mencerminkan citra produk yang dikemas dan mudah dipahami oleh konsumen karena ilustrasi gambarnya.

5. Faktor Ergonomi

Kemasan memiliki bentuk yang memudahkan dalam penyajian dan penyantapan produk, selain itu kemasan mempunyai sistem double drain untuk membuang air sisa penyeduhan mi agar konsumen tidak terkena air panas seduhan mi.

6. Faktor Identitas

Produk mudah dikenali karena bentuk kemasan yang unik dibandingkan mi dalam kemasan lainnya yang bentuknya cenderung meninggi, dengan bentuk seperti mangkok dan desain kemasan berwarna merah menjadi salah satu penarik konsumen.

7. Faktor promosi

Kemasan telah mempromosikan produk dengan baik, karena desain kemasan dan bentuk kemasan yang berbeda dengan produk merek lain yang sejenis membuat konsumen mudah melihat dan membedakan produk.

8. Faktor Lingkungan

Kemasan menggunakan dua macam tipe plastik untuk kemasan primer, kemasan awal adalah plastik sekali pakai yang tidak bisa didaur ulang dan plastik polypropylene yang aman untuk menyajikan makanan dengan suhu tinggi dan masih bisa didaur ulang

\section{SIMPULAN}

Dapat disimpulkan bahwa kemasan Mi U.F.O Nissin Food memiliki daya tarik visual dan daya tarik praktis yang bisa dibilang sangat baik. Dari visual, kemasan ini menonjol dibandingkan dengan produk sejenis dengan merek lain karena menggunakan warna merah yang mampu menarik perhatian juga dengan ilustrasi foto yang juga bisa menarik perhatian konsumen untuk membeli produk ini, informasi bahan-bahan, penyajian produk dan tanggal kadaluarsa produk juga tertata jelas walaupun ukuran font terbilang kecil, sedangkan dari segi fungsional, telah dipertimbangkan dengan cukup baik, dengan ukuran, bentuk kemasan yang berbeda dengan produk lain juga penggunaan material plastik polypropylene yang membuat kemasan ini lebih aman untuk digunakan daripada kemasan produk sejenis yang masih menggunakan Styrofoam yang tidak ramah lingkungan. Penulis berharap kedepannya akan banyak produk dengan kemasan yang ramah lingkungan dan kreatif lainnya dalam industri pengemasan di Indonesia.

\section{DAFTAR PUSTAKA}

Erlyana, Y., \& Nadya. (2018). Analisis desain kemasan mi instan edisi khusus indomie tempo doeloe. 1(1), 17-29.

Everlin, S., \& Yosephine, C. (2018). ANALISIS DESAIN KEMASAN YOGURT DRINK 'CIMORY 'Analysis of 'Cimory' Yogurt Drink Packaging. 1, 109-121.

Julianti, S. (2014). The Art of Packaging. 
Klimchuck, M. rosner, \& Krasovec, S. A. (2007). Desain Kemasan. PT. Gelora Aksara Pratama. www.nissinfoods.co.id. (2016). MI U.F.O NISSIN FOOD. 